\title{
CORPORATE LIQUIDITY AND FINANCIAL INDICATORS IN SELECTED SECTORS IN THE CZECH REPUBLIC
}

\author{
[Likvidita podniků a finanční ukazatele ve vybraných odvětvích v České \\ republice]
}

\author{
Markéta Šeligová ${ }^{1}$ \\ ${ }^{1}$ Slezská univerzita, Obchodně podnikatelská fakulta, Univerzitní nám. 1934/3,733 40 Karviná \\ Email:seligova@opf.slu.cz
}

\begin{abstract}
The aim of this paper is to determine the relationship between selected financial indicators and liquidity of companies (corporate liquidity) in selected sectors in the Czech Republic from 2000 to 2015. With the purpose to fulfill the aim, the existence and character of relationship between selected financial factors (debt equity ratio, return on equity, share of fixed assets to total assets, share of earnings before interest and taxes to total assets) and liquidity of the companies in sectors such as mining and quarrying, manufacturing, construction, service sector and energy sector will be examined. The aim of this paper is also to find out how the liquity of companies affects the debt equity ratio, return on equity and share of fixed assets to total assets. The existence of relationship between selected financial factors and liquidity of companies is tested by correlation analysis and regression analysis. The results show that there is a negative impact of share of fixed assets to total assets on liquidity of companies in service sector in the Czech Republic. The liquidity of companies was positively influenced by the return on equity and negatively influenced by debt equity ratio in energy sector in the Czech Republic. On the other hand, it was found that liquidity of companies negatively affects debt equity ratio in energy sector in the Czech Republic. There was also found that liquidity of companies negatively affects the share of fixed assets to total assets. The impact of other selected variables on corporate liquidity has not been demonstrated in other selected sectors.
\end{abstract}

Keywords: correlation, debt equity ratio, fixed assets, leverage ratio, liquidity, regression analysis, return on ekvity.

JEL classification: G32

Doručeno redakci: 25.10.2017; Recenzováno: 14.11.2017; 24.11.2017; Schváleno k publikování: 13.12.2017

\section{Introduction}

Myers (2001) argues that agency effects of various kinds may create important reasons for holding liquid assets with the further implications of different patterns of corporate liquidity depending on capital structure or other firm characteristics. He believed that holding liquid assets will be important for companies facing growth opportunities and the expected return fluctuates over time. Given that the decision on liquidity associated with the debt structure of companies, each of them needs to monitor its liquidity relations following the decision of debt. Liquidity is a key financial indicator to measure whether the company is able to meet its debt obligations based on short-term debt ratio, long-term debt ratio and total debt ratio without causing undesirable losses. Stulz (1990) argues that firms with high leverage and losing their financial flexibility, may have difficulty in finding new funds to finance their projects. Šarlija and Harc (2012) suggest that liquidity is a characteristic of the company's assets that can be quickly converted to cash. Firms hold a certain amount of liquidity in during their activities to be able to meet its obligations on time. For this reason, Saleem Rehman (2011) argues that liquidity management is very important for each company in order to maintain the ability to pay its obligations properly and on time.

The aim of this paper is to determine the relationship between selected financial indicators and liquidity of companies (corporate liquidity) in selected sectors in the Czech Republic 
from 2000 to 2015. With the purpose to fulfill the aim, the existence and character of relationship between selected financial factors (debt equity ratio, return on equity, share of fixed assets to total assets, share of earnings before interest and taxes to total assets) and liquidity of the companies in sectors such as mining and quarrying, manufacturing, construction, service sector and energy sector will be examined. The aim of this paper is also to find out how the liquity of companies affects the debt equity ratio, return on equity and share of fixed assets to total assets. The first part of this article will include a literature review. The second part of this article will focuse on methodology and data. The third part of this article will contain results and discussion. Last part of this article will conclude the results.

\section{Literature Review}

Williamson (1988), Schleifer and Vishny (1992), Anderson (2002) believe that more liquid companies are less costly to monitor and liquidate therefore higher liquidity growth leverage. On the contrary, De Jong et al. (2008), Lipson and Mortal (2009), Sarlija and Harc (2012) argue that more liquid companies are less indebted, because they could use the additional liquidity to finance their activities internally.

The aim of this paper is to determine the relationship between selected financial indicators and liquidity of companies (corporate liquidity) in selected sectors in the Czech Republic. For this reason, it would be appropriate to mention a study focusing on the liquidity of companies in the Czech Republic. Unfortunately, there are few studies focusing on the liquidity of companies in the Czech Republic. For this reason, the literature review will be supplemented with additional relevant studies focusing on the liquidity of companies in other countries.

Anderson (2002) examined the relationships among the firm's financial structure, its choice of liquid asset holdings and growth on UK and Belgian companies. Using regression analysis he examined the factors determining liquid asset holdings and the link between firm liquidity and capital structure using the following variables: liquidity (dependent variable, sum of cash, bank balances and investments in current assets divided by total assets) and independent variables such as cash flow (earnings before taxes and interest divided by total assets), long term debt, medium term debt, short term debt, R\&D expenditures and market value to book value. The results revealed positive associations between leverage and liquid asset holding.

One of selected financial indicators affecting corporate liquidity is depreciation that is related with fixed assets. For this reason, it is appropriate to examine the relationship between liquidity of companies and depreciation through fixed assets. Unfortunately, there is only minimum specific studies that focus on this relationship. For this reason, study of Mehar (2005) was selected to the literature review. He examined whether equity financing plays a central role in determination of the liquidity position of a companies in Pakistan. The relation between the equities and working capital has been observed. He analyzed relation between liquid assets (dependent variable) and independent variables such as fixed assets at historical cost, net profit after tax and retained earnings. There was found that liquidity is positively correlated with fixed assets. An increase in the fixed assets will lead to the increase in depreciation expenditure, so availability of the funds will be increased without a decline in the cash balance. He found that depreciation fund has been classified as a source of liquidity. The long-term debt may deteriorate the liquidity position of a firm. The results shows that profit and liquidity have significant positive relation where relation between liquidity and retained earnings was found as negative. On the other hand, Sibilkov (2007) found that liquidity increases the costs of managerial decision-making and that the effect of liquidity of assets on leverage is conditioned by a combination of hedged receivables and a direct relationship between liquidity and unsecured debt. He also confirmed that liquidity increases with growth 
indebtedness in highly indebted firms. He also confirmed that liquidity is increasing in companies with low interest coverage and a low value of fixed assets. Hrdý (2011) sees the importance of an optimal capital structure of a company in the fact that it also derives an interest rate from discounting future cash flows in investment decision making. In this context, an important aspect of corporate liquidity is that a company can take advantage of investment opportunities or the adverse economic or business conditions.

Shah (2012) examined relationship between profitability and liquidity trade off through the application of working capital analysis in India. This study undertakes the identification of the key variables that influence the working capital management and its impact on profitability and liquidity of pharmaceuticals manufacturers. He examined the relationship between liquidity (dependent variable, including current ratio) and independent variables (components of working capital) such as gross operating cycle period and quick ratio. It has been found that there is a positive relationship between liquidity and variables such as quick ratio and gross operating cycle period. He examined the relationship between liquidity (current ratio) and profitability (earnings before depreciation, interest, and tax as a percentage of assets). It has been found that there is a negative relationship between liquidity and profitability.

Šarlija and Harc (2012) investigated the impact of liquidity on the capital structure of Croatian firms. Pearson correlation coefficient was applied to the test on the relationship between liquidity ratios and debt ratios, the share of retained earnings to capital and liquidity ratios and the relationship between the structure of current assets and leverage. The results showed the existence of a statistically significant negative correlations between liquidity ratios and leverage ratios. The results showed that there are statistically significant correlations between leverage ratios and the structure of current assets. The relationship between liquidity ratios and the short-term leverage is stronger and negative than positive relationship between liquidity ratios and the long-term leverage. The more liquid assets firms have, the less they are leveraged. Long-term leveraged firms are more liquid. Increasing inventory levels leads to an increase in leverage. Furthermore, increasing the cash in current assets leads to a reduction in the short-term and the long-term leverage. Trippner (2013) analyzed the relationship between liquidity (cash ratio, current ratio and quick ratio) and profitability (return on assets - ROA, return on equity - ROE) in the Polish companies from 2002 to 2012. Using correlation analysis it has been found that there is a positive and negative relation between liquidity and ROA and ROE.

Miloś (2015) analyzed the determinants of capital structure of the Romanian companies using panel data. He used variables including ratio between total debt and total liabilities, profitability (return on assets), liquidity (ratio between current assets and current liabilities), tangibility (ratio of tangible assets divided by the total assets) and size (natural logarithm of total sales). The results show that there is a negative connection between liquidity and leverage. The results suggest that less liquid companies obtain the necessary capital by borrowing. Companies often prefer and use a short-term loans when there is a lack of liquidity. Růčková (2014) focused on whether the conditions in selected sectors in the Czech Republic are based on the theoretical assumption that the low level of profitability is associated with high liquidity and vice versa. There was a negative correlation between the profitability and liquidity of the service sector. Construction has shown little or no relationship between liquidity and profitability. For the other monitored sectors (energy, manufacturing and mining) a positive correlation was found. Růčková (2015) analyzed the impact of liquidity and profitability on use of debt finance sources of companies in manufacturing industry in V4 countries. She examined the relationship between using debt 
sources (debt/equity ratio) and liquidity. The study results showed a positive relationship between liquidity and using debt sources in the Czech Republic. It can be stated that the increasing liquidity of companies is also increasing the using debt sources.

\section{Data and Methodology}

Given that the article focuses on liquidity of companies in the Czech Republic, it is appropriate to mention that various sectors of the economy are involved to varying degrees in the consumption and production of the national economy. The sectors such as mining and quarrying, manufacturing, construction, service sector and energy sector represent the largest proportion of the performance of the Czech economy. For this reason, the article focuses on determination the relationship between the selected financial indicators and liquidity of the companies in mining and quarrying, manufacturing, construction, service sector and energy sector.

The financial data are taken from Ministry of Trade and Industry in the Czech Republic. The data include data from annual reports of individual companies in selected sectors in the Czech Republic. The dataset cover the period 2000-2015. All the data and time series are on annual frequency. A representative sample involves large companies, medium-sized companies, small companies and tradesmen within each industry. The data representative of more than $50 \%$ of the companies in the sector is considered to be sufficiently representative. The data are the basis for the application of correlation analysis and regression analysis. The sample examined includes 27 companies in mining and quarrying companies, 1265 companies in manufacturing, 166 companies in construction, 646 companies in service sector and 80 companies in energy sector.

Figure 1: Corporate Liquidity in Selected Sectors in the Czech Republic (in units)

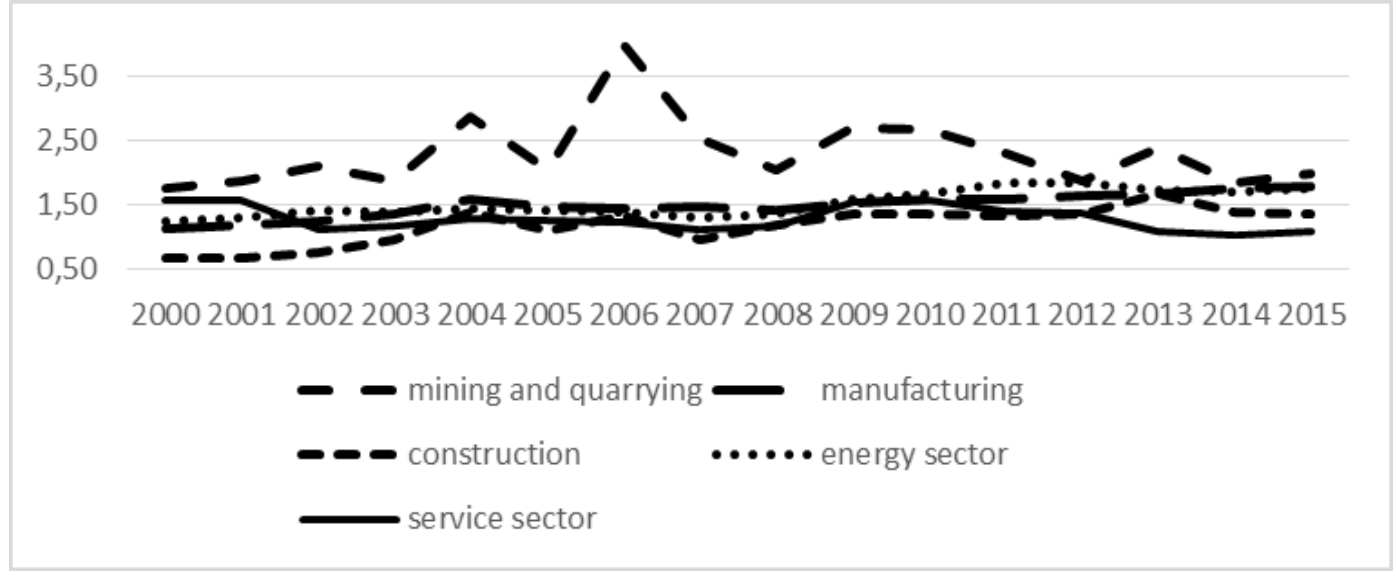

Source: Authors' calculations

Figure no 1 depicts development of corporate liquidity (L3; current ratio) in selected sectors such as mining and quarrying, construction, manufacturing, service sector and energy sector in the Czech Republic from 2000 to 2015 . The figure no 1 shows that the corporate liquidity reached almost a rising trend during the analysis period in manufacturing, construction, service sector and energy sector. The highest value of corporate liquidity was about 2 in energy sector in 2012. The lowest value of liquidity was around 0.7 in construction from 2000 to 2001. In mining and quarrying, there was recorded alternating trend. The highest value of liquidity was about 3.8 in 2006. The lowest value was about 1.4 from 2013 to 2015. The liquidity value should be from 1.5 to 2.5 . The figure no 1 shows that liquidity of companies fulfill the recommended values from 2003 to 2015 in manufacturing, construction, service sector and energy sector. In mining and quarrying, liquidity of companies fulfill the 
recommended values during the whole analysis period excluding the period from 2005 to 2007.

Figure 2: Development of Companies in Selected Sectors in the Czech Republic

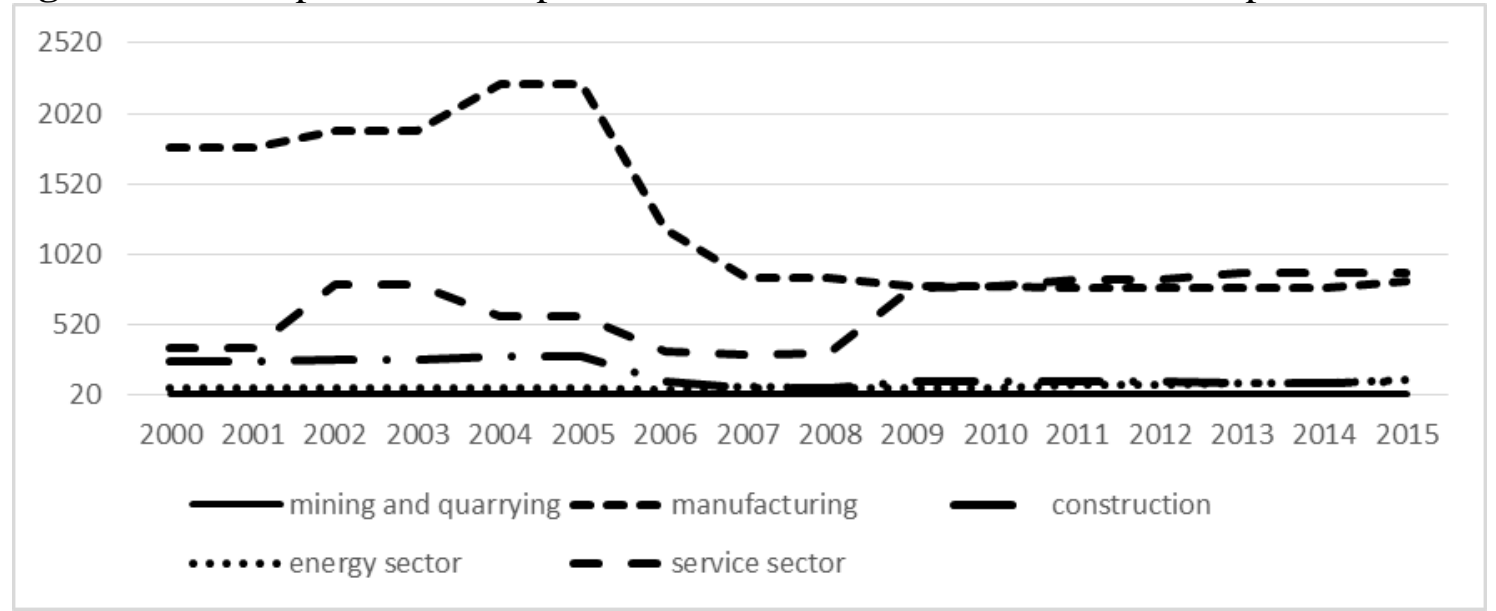

Source: Authors' calculations

Figure no 2 depicts development of companies in sectors such as mining and quarrying, manufacturing, construction, energy sector and service sector in the Czech Republic from 2000 to 2015. The $x$ axis represents years and y axis represents number of companies in the analyzed sectors. From this figure is obvious that the largest number of companies was recorded in manufacturing. The second largest number of companies was recorded in service sector. On the other hand, the smallest number of companies was in energy sector, mining and quarrying and construction. It can be argued that companies showed an alternating trend in manufacturing and service sector. Number of companies has fallen in half during crisis period. On the contrary, companies showed a growing trend during crisis period in service sector. On the other hand, companies showed a steady trend in energy sector and mining and quarrying.

The relationship between liquidity of companies and selected financial indicators can be defined based on the above studies and formulated goals. This relationship will be identified for various sector (mining and quarrying, manufacturing, construction, service sector and energy sector). It will be examined how selected financial indicators affect liquidity of companies. Correlation analysis, regression analysis and OLS method are used to determine the relationship between liquidity of companies and selected financial indicators. First, the relationship between liquidity of companies and selected financial indicators can be determined using Pearsnon's correlation coefficient (1):

$$
P_{X Y}=\frac{\operatorname{cov}(X, Y)}{\sigma_{X} \sigma_{Y}}
$$

Where $\mathrm{X}$ is the mean value matrix liquidity of companies and $\mathrm{Y}$ is the mean value matrix of debt equity ratio, return on equity, share of fixed assets to total assets, share of earnings before interest and taxes to total assets. This indicator should be in the interval from -1 to 1 . Values closer to the value of 1 would suggest that with increased liquidity of companies there is a growth of debt equity ratio, return on equity, share of fixed assets to total assets, share of earnings before interest and taxes to total assets. Values closer to the value of -1 would suggest that with decreased liquidity of companies there is a growth of debt equity ratio, 
return on equity, share of fixed assets to total assets, share of earnings before interest and taxes to total assets. Values which are zero signal independent of one another.

The construction of a regression model will be based on the study Anderson (2002). The individual model variables are consistent with the above studies. The relationship between liquidity of companies and selected financial indicators will be estimated using the following equations in general form (2):

$$
L_{t}=\beta_{0}+\beta_{1} X_{1 t}+\beta_{2} X_{2 t} \ldots \ldots \ldots \ldots+\beta_{n} X_{n t}+\varepsilon_{t}
$$

The dependent variable is an indicator of current liquidity (L3) of companies in the Czech Republic at time t, $\quad \beta$ are other factors that represent selected financial indicators and which may affect the liquidity of companies in the Czech Republic. These factors include debt equity ratio (DER), return on equity (ROE), share of fixed assets to total assets (FATTA), share of earnings before interest and taxes to total assets (EBIT). $\varepsilon_{t}$ and is model constant and the residual component in the model. Current liquidity (L3) determines and measures the payroll capacity of a company as a rule over a short period (most often calculated monthly). Current liquidity (L3) includes current assets that are the least liquid assets but are not considered to be illiquid assets. For this reason, current liquidity (L3) was included in the research. Liquidity will be included in the equation as an independent variable. The following equation is used to determine the effect of liquidity on the debt equity ratio, return on equity and the share of fixed assets in total assets:

$$
Y_{t}=\beta_{0}+\beta_{1} X_{1 t}+\varepsilon_{t}
$$

The dependent variable for the first model is the debt equity ratio, for the second model is return on equity and for the third model the share of fixed assets in total assets at time t, $\beta_{0}$ je konstanta, $\beta_{1}$ is an indicator of current liquitiy (L3) of companies and $\varepsilon_{t}$ is model constant and the residual component in the model.

Table 1: Description of used variables

\begin{tabular}{|l|l|c|}
\hline Variables & Calculation & Expected relationship \\
\hline Liquidity (L3) & Current assets/ current liabilities & Dependent variable \\
\hline Debt equity ratio (DER) & Debt/equity & - \\
\hline Return on equity (ROE) & Net profit/ equity & $+/-$ \\
\hline Fixed assets (FATTA) & Fixed assets/total assets & $+/-$ \\
\hline $\begin{array}{l}\text { Earnings before interest and taxes } \\
\text { (EBIT) }\end{array}$ & $\begin{array}{l}\text { Earnings before interest and } \\
\text { taxes/total assets }\end{array}$ & $+/-$ \\
\hline
\end{tabular}

Source: Authors' calculations

Table no 1 represents description of used variables. The selected financial indicators are represented through the four variables (debt equity ratio, return on equity, share of fixed assets to total assets, share of earnings before interest and taxes to total assets). The five ratios (variables) are used to determine relationship between selected financial indicators and liquidity of companies. The choice of variables is based on the above studies.

The econometrics software EViews 9 was used. First, it is necessary to determine if the time series do not contain outlying observations. For this reason, the data interpolation method using the linear trend have been applied for detecting and dealing with outlying observations. Then, it is necessary to test the time series for the stationarity before estimating the model. 
The Levin, Lin and Chu test was used to test the individual variables for the existence of the unit roots. The result of the test indicates that the variables are not stationary on the values. So that the null hypothesis of a unit root can be taken. For this reason, it was necessary to use the fist difference. Then, all times series are stationary and can be used in regression analysis. Ordinary Least Squares (OLS) method has several prerequisites. First, White test is used for correction of heteroscedasticity. Using this test the heteroscedasticity was rejected and the error term is homoscedastic. For detecting multicollinearity correlation coefficient was used. The correlation matrix showed that any variables are not correlated together. It was found normality of the error term, thus the prerequisite that the residual must have normal probability distribution. The absence of autocorrelation of the error term is determined by the Durbin-Watson test. The Durbin-Watson statistic (DW) is used for testing autocorrelation in the residuals.

\section{Results and Discussion}

This part focuses on the results of correlation analysis, regression analysis and their comments. First, the relationship between liquidity of companies and selected financial indicators will be determined using correlation analysis. The following table (2) reflects the degree of interdependence of monitored parameters in selected sectors in the Czech Republic.

Table 2: Correlation between liquidity of companies and selected financial indicators in selected sectors

\begin{tabular}{|l|l|l|l|l|l|}
\hline & Liquidity & DER & ROE & FATTA & EBIT \\
\hline $\begin{array}{l}\text { mining and } \\
\text { quarrying }\end{array}$ & Liquidity L3 & 0.327676 & -0.213947 & $-0.727376 *$ & -0.309519 \\
\hline manufacturing & Liquidity L3 & 0.141195 & 0.271813 & $-0.423893 * * *$ & 0.216988 \\
\hline construction & Liquidity L3 & $-0.391987 * *$ & 0.206347 & -0.100032 & 0.160306 \\
\hline service sector & Liquidity L3 & -0.133967 & -0.196059 & -0.304793 & -0.296926 \\
\hline energy sector & Liquidity L3 & -0.473280 & 0.388364 & 0.254006 & 0.320249 \\
\hline
\end{tabular}

Source: Authors' calculations

Note: * denotes significance at $1 \%$ level, ** denotes significance at $5 \%$ level, *** denotes significance at $10 \%$ level

Table 2 presents correlative relationship between liquidity companies (dependent variable) and independent variables such as debt equity ratio, return on equity, share of fixed assets to total assets, share of earnings before interest and taxes to total assets. From this table (1) it is evident that correlation is different for all variables and selected sectors in the Czech Republic. The relationship between liquidity of companies and debt equity ratio (DER), return on equity (ROE) and share of earnings before interest and taxes to total assets (EBIT) appears as uncorrelated in all the selected sectors. The correlation is close to 0 . In this fact, the most significant correlation was observed in the energy sector.

The correlation coefficient is $-0,473280$ for relationship between liquidity of companies and debt equity ratio. This means that there is a negative correlation between liquidity of companies and debt equity ratio (DER). This result suggests that with a decrease in debt equity ratio increases liquidity of companies in mining and quarrying in the Czech Republic. The results also suggest that the correlation coefficient is (+) 0,388364 for relationship between liquidity of companies and return on equity (ROE) and (+) 0,320249 for relationship between liquidity of companies and share of earnings before interest and taxes to total assets (EBIT). There is a positive correlation between liquidity of companies and variables such as return on equity (ROE) and share of earnings before interest and taxes to total assets (EBIT). This means that with increase in return on equity and share of earnings before interest and 
taxes to total assets leads to increase liquidity of companies in energy sector in the Czech Republic.

The results suggest that the relationship between liquidity of companies and share of fixed assets to total assets (FATTA) appears as uncorrelated in manufacturing, construction, service sector and energy sector. Within mining and quarrying, the negative correlation was observed between liquidity of companies and share of fixed assets to total assets (FATTA). The correlation $(-0,727376)$ is close to -1 . It can be stated that with a decrease in share of fixed assets to total assets (FATTA) leads to increase liquidity of companies in mining and quarrying in Czech Republic. Despite the above, it is necessary to take into account the fact that the correlation is statistically significant only for three relation. There was recorded negative significant correlation at $1 \%$ level for relationship between liquidity of companies and share of fixed assets to total assets (FATTA) in mining and quarrying. The correlation was about -0.727376 . There was recorded negative significant correlation at $10 \%$ level for relationship between liquidity of companies and share of fixed assets to total assets (FATTA) in manufacturing. The correlation reached about -0.423893 . There was recorded negative significant correlation at $5 \%$ level for relationship between liquidity of companies and debt equity ratio (DER) in construction. The correlation was about -0.391987 .

Using correlation analysis it was found that there is a positive, negative and no relationship between liquidity of companies in selected sector in the Czech Republic and independent variables (selected financial indicators). Regression analysis and Ordinary Least Squares (OLS) method will be used to determine, how significant the relationship between liquidity of companies and selected financial indicators will be. Table 3 presents the resulting relationship between liquidity companies (dependent variables) and selected financial indicators (independent variables).

Table 3: Estimation results between liquidity of companies and selected financial indicators in selected sectors

\begin{tabular}{|l|l|l|l|l|}
\hline & \multicolumn{2}{|l|}{ Energy sector } & Service sector \\
\hline & Coefficient & t-statistics & Coefficient & t-statistics \\
\hline Constant & 0.004798 & 0.104066 & -0.019634 & -0.425631 \\
\hline DER & $-0.624761 * *$ & -2.516879 & - & - \\
\hline FATTA & - & - & $-2.612102 * *$ & -2.138445 \\
\hline ROE & $3.869004 * *$ & 2.758368 & - & - \\
\hline R-squared & 0.634676 & 0.397842 & 0.156979 \\
\hline $\begin{array}{l}\text { Adjusted } \\
\text { R-squared }\end{array}$ & 0.472310 & 1.651734 & \\
\hline F-statistic & 3.908916 & 0 & \\
\hline Prob(F-statistic) & 0 & 1.821626 & \\
\hline Durbin-Watson stat & 1.893395 & & \\
\hline
\end{tabular}

Source: Authors' calculations

Note: * denotes significance at $1 \%$ level, ** denotes significance at $5 \%$ level, *** denotes significance at $10 \%$ level

This table (3) suggests that different variables affect the liquidity companies in selected sectors in the Czech Republic from 2000 to 2015. The selected sectors include mining and quarrying, manufacturing, construction, service sector and energy sector. The relationship between liquidity of companies and selected financial indicators in all selected sectors was examined. The statistically significant variables were found only in two sectors (energy sector and service sector). For this reason, table no 3 represents results of these two sectors. Some 
of the independent variables were not statistically significant, thus we are not able to confirm the impact of these variables on liquidity of companies in the Czech Republic. For this fact, table no 3 indicates only statistically significant variables that have impact on liquidity of companies in the Czech Republic.

As regards the energy sector, the empirical analysis shows that there is a negative impact of debt equity ratio (DER) on liquidity of companies. The table shows that the increase of debt equity ratio of unit decreases the liquidity of companies of 0,624761 units. This impact is confirmed in the studies of Miloś (2015) who found negative relationship between liquidity and debt equity ratio. Less liquid companies obtain the necessary capital by borrowing. Companies often prefer and use a short-term loans when there is a lack of liquidity. It can be argued that the more liquid the firm is, it is the less leveraged.

The results also suggest that there is a positive impact of return on equity (ROE) on liquidity of companies. The results suggest that the increase of return on equity of unit increases the liquidity of companies of 3,869004 units. This result confirms the findings of Trippner (2013) who found positive relationship between liquidity of companies and return on equity (ROE). More profitable companies are the ones that can use their retained earnings in order to finance their investment projects. It can be argued that the more liquid the firm is, it is the less leveraged. If companies are profitable, then their free cash is growing under otherwise unchanged conditions, the risk of availability of funds in general is diminishing and, at the same time, the availability of debt financing on favorable terms in terms of debt costs is increasing.

As regards the service sector, the results indicate that there is a negative impact of share of fixed assets to total assets (FATTA) on liquidity of companies. The share increase of fixed assets to total assets of unit decreases the liquidity of companies of 2,612102 units. This result is not confirmed by any of the above study. The resulting relationship can be explained in the following argument. Assets of the company can be divided into fixed assets and current assets. The liquidity of the company consists of current assets. Liquidity growth should be accompanied by an increase in current assets. This argument shows that the growth in current assets is accompanied by a decrease in fixed assets. From this fact can be inferred negative relationship between liquidity of company and fixed assets. All identified resulting relationships correspond with the conclusions of correlation analysis through which it was determined what relationship exists between liquidity of companies and independent variables.

Within determination of the influence of selected financial indicators on liquidity of companies it is also necessary to take into account the significance of the model, which is primarily low in the service sector. R-squared value is about $40 \%$ and Adjusted R-squared is about $15 \%$. In the energy sector, there is R-squared value about $63 \%$ and Adjusted Rsquared about $47 \%$. The table no 3 reveals that the explanatory power of the model is low. For this reason, opposite relationship between liquidity companies and selected financial indicators will be estimated when the impact of liquidity of companies on selected financial indicators will be examined. Table 4 presents the resulting relationship between selected financial indicators (dependent variables) and liquidity of companies (independent variable). 
Table 4: Estimation results between selected financial indicators and liquidity of companies in selected sectors

\begin{tabular}{|c|c|c|c|c|}
\hline & \multicolumn{2}{|c|}{ Energy sector } & \multicolumn{2}{|c|}{ Mining and quarrying } \\
\hline & \multicolumn{2}{|c|}{ Dependent variable } & \multicolumn{2}{|c|}{ Dependent variable } \\
\hline & \multicolumn{2}{|l|}{ DER } & \multicolumn{2}{|l|}{ FATTA } \\
\hline & Coefficient & t-statistics & Coefficient & t-statistics \\
\hline Constant & 0,007488 & -1.861129 & $-0,004516$ & -0.515872 \\
\hline L3 & $-0.488843 * *$ & -1.861129 & $-0,042761 *$ & -3.821688 \\
\hline R-squared & \multicolumn{2}{|l|}{0.223994} & \multicolumn{2}{|l|}{0.529076} \\
\hline $\begin{array}{l}\text { Adjusted } \\
\text { R-squared }\end{array}$ & \multicolumn{2}{|l|}{0.159327} & \multicolumn{2}{|l|}{0.492851} \\
\hline F-statistic & \multicolumn{2}{|l|}{3.463800} & \multicolumn{2}{|l|}{14.60530} \\
\hline Prob(F-statistic) & \multicolumn{2}{|l|}{0} & \multicolumn{2}{|l|}{0} \\
\hline Durbin-Watson stat & \multicolumn{2}{|l|}{2.111524} & \multicolumn{2}{|l|}{1.87395} \\
\hline
\end{tabular}

Source: Authors' calculations

Note: * denotes significance at $1 \%$ level, ** denotes significance at $5 \%$ level, *** denotes significance at $10 \%$ level

From this table (4) it can be claimed that liquidity of companies affects various selected financial indicators in selected sectors in the Czech Republic from 2000 to 2015. The statistically significant relationship was found only in two sectors (energy sector and mining and quarrying). For this reason, table no 4 represents results of these two sectors. As regards the energy sector, the empirical results indicate that there is a negative impact of corporate liquidity on debt equity ratio (DER). The results show that decrease of liquidity of companies of unit increases debt equity ratio of 0.488843 units. This impact is confirmed in the study of Miloś (2015) who found negative relationship between liquidity and debt equity ratio. Less liquid companies obtain the necessary capital by borrowing. Companies often prefer and use a short-term loans when there is a lack of liquidity. It can be argued that the more liquid the firm is, it is the less leveraged.

In the mining and quarrying, the empirical analysis shows that there is a negative impact of liquidity of companies on share of fixed assets to total assets (FATTA). It means that decrease of liquidity of companies of unit increases the share of fixed assets to total assets of 0,042761 units. This result is not confirmed by any of the above studies. This can be explained by argumentation finding relationship between liquidity of companies and share of fixed assets to total assets described in the context table 3 . These observed results correspond with the results which are described in table 3 . It is necessary to take into consideration the significance of the model, which is very low in the energy sector. R-squared value is about $22 \%$ and Adjusted Rsquared is about $16 \%$. In the sector of mining and quarrying, there is R-squared value about $53 \%$ and Adjusted-R-squared is about $49 \%$. The table no 4 indicates that the explanatory power of the model to determine the impact of liquidity of companies on selected financial indicators is as low as in the case of a model that estimated the impact of selected financial indicators on liquidity of companies (table 3). Based on the results it is evident that the liquidity of companies is affected by other factors (variables) that have not been tested. Based on this fact may be provided another area for any further exploration in the future.

\section{Conclusion}

The aim of this paper was to determine the relationship between selected financial indicators and liquidity of companies (corporate liquidity) in selected sectors in the Czech Republic from 2000 to 2015. The aim of this paper is also to find out how the liquity of companies affects the debt equity ratio, return on equity and share of fixed assets to total assets. First, the impact of selected financial indicators (debt equity ratio, return on equity, share of fixed 
assets to total assets, share of earnings before interest and taxes to total assets) on liquidity of companies in mining and quarrying, manufacturing, construction, service sector and energy sector in the Czech Republic was examined. Then, the impact of liquidity of companies on selected financial indicators (debt equity ratio, return on equity, share of fixed assets to total assets, share of earnings before interest and taxes to total assets) in mining and quarrying manufacturing, construction, service sector and energy sector in the Czech Republic was examined.

It was found that the liquidity of companies was positively influenced by the return on equity (ROE) in energy sector in the Czech Republic. This means that with increase in return on equity increases liquidity of companies in energy sector in the Czech Republic. From the above, it can be concluded that if a company has high liquidity ratios, it is generally beneficial and desirable for it. The effort of each company is to maintain a high proportion of current assets, thereby creating a good image for potential investors and creditors. If the company has high liquidity, it means that it is able to repay its obligations on time and in full. In order to maintain the existence of long-term prosperity, it is not enough just to maintain a reasonable level of liquidity. It is also necessary to effectively manage the company's resources. The basic economic indicator of economic efficiency is profitability. A prerequisite of good profitability is the appreciation of the funds invested in such a way that they not only cover all the investment costs but also bring some return to the company. For a healthy and lasting business, it is therefore necessary to achieve some profitability while maintaining the optimum liquidity level. Since economic units with less liquid assets usually achieve higher rates of return, the opposite trends in return between profitability and liquidity can usually be seen. If a company keeps a large amount of current assets, it leads to a reduction in profitability, as there is very little or no interest in holding those funds. On the other hand, highly profitable companies are able to reap further business activities from their profits, pay dividends to shareholders, and create a financial cushion in case of unexpected facts.

On the other hand, debt equity ratio (DER) has a negative impact on liquidity of companies in energy sector. It is also necessary to take into account the preferences of using equity or debt within each sector. For the energy sector and the service sector, there is typically more use of debt capital to finance its business activities. It can be stated that with decrease in debt equity ratio increases liquidity of companies in energy sector in the Czech Republic. It can be argued that the more liquid the firm is, it is the less leveraged. Completely different situation was recorded in the service sector. There was observed the resulting relationship between liquidity of companies and share of fixed assets to total assets. The debt ratio ratio measures debt sources to equity. The higher the value of the debt equity ratio, the higher the company's indebtedness. Indebtedness generally does not have to be a negative feature of the company. Its growth in a stable company contributes to increasing profitability (the leverage effect). With increasing indebtedness, however, there is a growing risk that the company will have problems repaying interest and get into an unfavorable financial situation. The smaller the company uses, the more security pillow against loss of creditors in case of liquidation. Therefore, lenders prefer a low indebtedness index. Owners, on the other hand, are looking for more financial leverage to multiply their returns. If a company is highly indebted, it will be difficult for it to obtain additional resources without first raising its own capital. Creditors will be reluctant to lend money to the company or demand a higher interest rate. An adequate level of equity and debt capital can also not be determined without reference to the liquidity of the companies. Companies with a very stable liquidity position can afford higher indebtedness. On the other hand, high indebtedness can lead to a reduction in liquidity. In order to assess the relationship between liquidity and indebtedness development, it is 
necessary to analyze the structure of debt funding sources by maturity. If a company has a high proportion of short-term and fast-paced assets and a low value of current assets relative to the value of short-term debt sources, it may have liquidity problems. If there is a high proportion of long-term debt sources, this problem may not arise. Companies with a high level of debt are less able to dispose of sufficient liquidity in energy sector. These results shows the lower value of the debt equity ratio in energy sector is accompanied by higher liquidity, confirming the negative relationship between the debt equity ratio and the liquidity of companies in the energy sector. The high value of debt sources may be favorable from the point of view of the owners, provided that the company is able to achieve a higher percentage of return on assets than the percentage of interest paid from debt capital.

The results showed that there is a negative impact of share of fixed assets to total assets (FATTA) on liquidity of companies which means that with decrease in share of fixed assets to total assets increases liquidity of companies in service sector in the Czech Republic. The resulting relationship can be explained in the following argument. Assets of the company can be divided into fixed assets and current assets. The liquidity of companies consists of current assets. Liquidity growth should be accompanied by an increase in current assets. From this argument it shows that the growth in current assets is accompanied by a decrease in fixed assets. From this fact can be inferred negative relationship between liquidity of company and fixed assets. In practice, this means that if companies in the service sector have a higher fixed asset volume, which also involves a higher level of depreciation, they have a lower liquidity level. If companies in the service sector have lower fixed assets, which also involves a lower depreciation level, they have a higher liquidity level. On the other hand, it was found that liquidity of companies negatively affects debt equity ratio in energy sector in the Czech Republic. This means that with decrease in liquidity of companies leads to an increase debt equity ratio in energy sector. There was also found that liquidity of companies negatively affects the share of fixed assets to total assets. It can be stated that with decrease in liquidity of companies leads to an increase the share of fixed assets to total assets. The results can be used in practice by both firms and industry sectors. If companies are highly indebted, they may signal or predict potential liquidity and solvency problems. Conversely, when companies have higher returns, they can expect higher liquidity in the form of a financial pillow and ability to pay.

\section{Acknowledgement}

„This paper was supported by the Ministry of Education, Youth and Sports Czech Republic within the Institutional Support for Long-term Development of a Research Organization in 2017 .

\section{References}

[1] ANDERSON, R. W., 2002. Capital structure, firm liquidity and growth. Working papersresearch series. National Bank of Belgium. [online]. Available at: www.nbb.be/doc/ts/publications/wp/WP27en.pdf. [Accessed: 1 January 2017].

[2] DE JONG, A., R. KABIR, and T. T. NGUYEN, 2008. Capital structure around the world: the roles of firm and country-specific determinants. Journal of banking and finance, 32(9), 1954-1969. ISSN 0378-4266.

[3] HRDÝ, M., 2011. Optimalizace kapitálové struktury konkrétního podniku věc teoreticky či prakticky možná. Český finanční a účetní časopis, 6(1), 19-32. ISSN 1802-2200.

[4] LIPSON, M. L. and S. MORTAL, 2009. Liquidity and capital structure. Journal of Financial Markets. 12(4), 611-644. ISSN 1386-4181. 
[5] MEHAR, A., 2005. Impacts of equity financing on liquidity position of a firm. Applied Financial Economics, Vol. 15, 425-438. ISSN 1466-4305.

[6] MILOŞ, M. C., 2015. Capital Structure Determinants. Evidence from the Romanian Listed Companies. Analele Universitatii 'Eftimie Murgu' Resita. Fascicola II. Studii Economice, 129-134. ISSN 2344-6315.

[7] MYERS, S. C., 2001. Capital structure. The journal of economic perspectives. 15(2), 81102. ISSN 0304-405X.

[8] RŮČKOVÁ, P., 2014. Vztah rentability, likvidity a hrubého domácího produktu v podmínkách České republiky. Český finanční a účetní časopis, 1, 140-147. ISSN 18022200 .

[9] RŮČKOVÁ, P., 2015. Impact of Liquidity and Profitability on Use of Debt Finance Sources of Companies in Manufacturing Industry in V4 Countries. Acta academica Karviniensia. 15(3), 69-79. ISSN 1212-415X.

[10] SALEEM, Q. and R. U. REHMAN, 2011. Impacts of liquidity ratios on profitability. Interdisciplinary Journal of Research in Business, 1(7), 95-98. ISSN 2249-4588.

[11] SHAH, P., 2012. Evaluation of Profitability and Liquidity Relationship through Multivariate Working Capital Analysis. A Management Journal, 3(2), 177. ISSN 23485302.

[12] SCHLEIFER, A. and R. W. VISHNY, 2001. Stock Market Driven Acquisitions. Journal of Financial Economics [online]. Available at: papers.ssrn.com/sol3/papers.cfm?abstract_id=278563. [Accessed: 28 February 2017].

[13] SIBILKOV, V., 2007. Asset liquidity and capital structure [online]. [vid. 2017-05-23] Available from: pantherfile.uwm.edu/sibilkov/www/liquidity.pdf

[14] STULZ, R., 1990. Managerial discretion and optimal financing policies. Journal of financial Economics, 26(1), 3-27. ISSN 0304-405X.

[15] ŠARLIJA, N. and M. HARC, 2012. The impact of liquidity on the capital structure: a case study of Croatian firms, Business Systems Research, 3(1), 30-36. ISSN 1847-9375.

[16] TRIPPNER, P., 2013. Analysis of Financial Liquidity Management in the Enterprise and its Impact on the Profitability. In: STAVÁREK, D. a P. VODOVÁ (ed). In: Proceedings of 14th International Conference on Finance and Banking. Karviná: Silesian University, School of Business Administration, s. 494-501. ISBN 978-80-7248-939-8

[17] WILLIAMSON, O. E., 1988. Corporate Finance and Corporate Governance. Journal of Finance, 43(3), 567-591. ISSN 1540-6261. 